\title{
ANALISIS PENGENDALIAN INTERNAL ATAS PERSEDIAAN PADA PERUM BULOG DIVRE SULUT
}

\author{
Julian Biga \\ Ventje Ilat \\ Inggriani Elim \\ Fakultas Ekonomi dan Bisnis Jurusan Akuntansi \\ Universitas Sam Ratulangi Manado \\ email :yulian_biga@ymail.com
}

\begin{abstract}
ABSTRAK
Persediaan merupakan aktiva lancar perusahaan yang jumlahnya cukup material dan merupakan salah satu faktor penting dalam penunjang aktivitas perusahaan. Karena itu harus dilakukan pengendalian internal yang baik untuk mengamankan persediaan dari tindakan pencurian, penyelewengan, dan kerusakan. Adapun dari tujuan penelitian ini adalah untuk mengetahui pengendalian internal yang dilakukan oleh Perum Bulog Divre Sulut guna mendapatkan gambaran yang jelas mengenai pengendalian internal persediaan beras yang diterapkan apakah sudah efektif. Metode yang digunakan dalam penelitian ini adalah metode deskriptif kualitatif yang digunakan untuk menggambarkan pengendalian internal persediaan pada Perum Bulog Divre Sulut. Dari hasil penelitian disimpulkan bahwa pengendalian internal persediaan beras pada Perum Bulog Divre Sulut sudah cukup efektif, dimana adanya pemisahan diantara fungsi-fungsi terkait dengan penerimaan dan pengeluaran beras. Pemantauan terhadap persediaan beras juga dilakukan tiap hari. Namun Perum Bulog Divre Sulut perlu memperbaiki kelemahan dalamperlindungan fisiknya yaitu dengan memasang kamera CCTV di dalam gudang untuk lebih menciptakan pengawasan internal persediaan yang efektif.
\end{abstract}

Kata kunci : Pengendalian internal, Persediaan.

\begin{abstract}
Supply constitutes a firm Current Assets, that its amount is material and constituting one of essential factor in corporate activity supporter. That is why it has to be done by a good internal control tosecure supplies of acts of fraud,deviation and demage. At one point, the purpose of this research is to know what is the internal control that did by Perum Bulog Divre Sulut in order to get a clear picture about the internal control of rice supply that is applied was effective or not. The method that is utilized in this research is qualitative descriptive method, this method will figure the internal control of supply in Perum Bulog Divre Divre Sulut. From the results of this research is concluded that the rice supply internal control by Perum Bulog Divre Sulut was effective, where there is a separation between functions that is concerning the rice input and output. The monitoring of rice supply is also been done everyday. But, the Perum Bulog Divre Sulut still need to fix their weaknesses in its physical protection with assembling CCTV camera at the storehouse to create an effective internal supply observation.
\end{abstract}

Keywords : Internal control, supply 


\subsection{Latar Belakang Masalah}

\section{PENDAHULUAN}

Setiap perusahaan dalam menjalankan kegiatannya berusaha untuk mengelolah semua sumber daya yang dimilikinya untuk mencapai tingkat efisien dan efektifitas yang optimal agar memperoleh laba. Hal ini bertujuan agar perusahaan dapat mampu bertahan dan bersaing dengan perusahan lain. Salah satu aset penting perusahaan dalam hubunganya untuk memperoleh pendapatan adalah persediaan. Persediaan tersebut merupakan aktiva lancar dimana informasinya sangat diperlukan oleh manajemen. Pengambilan keputusan yang baik terhadap persediaan akan mempertahankan kelangsungan usaha perusahaan.

Persediaan sangat rentan terhadap kerusakan maupun pencurian. Oleh karena itu diperlukan suatu pengendalian internal yang bertujuan untuk melindungi persediaan dan agar informasi mengenai persediaan lebih dapat dipercaya.Pengendalian internal persediaan dapat dilakukan dengan melakukan tindakan pengamanan untuk mencegah terjadinya kerusakan, pencurian, maupun tindakan penyimpangan lainnya.

Perusahaan Umum (Perum) Badan Urusan Logistik (BULOG) merupakan perusahaan milik negara yang bergerak dalam bidang logistic pangan. Bulog dalam melaksanakan fungsi dan tugas utamanya sebagai pengadaan, pengelolaan persediaan, dan distribusi beras, serta pengendalian harga beras maka Bulog harus dapat menyediakan kebutuhan akan beras kepada masyarakat. Tingginya frekuensi keluar masuk persediaan beras di bulog dikhawatirkan akan terjadi kehilangan atau pencurian stock beras, sehinggadiperlukan pengendalian internal persediaan yang baik agar tidak terjadi penyelewengan dalam menjalankan tugas.

\subsection{Perumusan Masalah}

Berdasarkan penjelasan latar belakang masalah diatas, maka penulis merumuskan masalah yaitu apakah penerapan pengendalian internal atas persediaan pada Perum Bulog Divre Sulut sudah berjalan dengan efektif?

\subsection{Tujuan Penelitian}

Adapun tujuan yang ingin dicapai dari penelitian ini adalah untuk mendapatkan gambaran yang jelas mengenai aplikasi dari pengendalian internal atas persediaan beras yang diterapkan oleh Perum Bulog Divre Sulut apakah sudah cukup efektif.

\subsection{Manfaat Penelitian}

1. Bagi penulis, dengan adanya penelitan ini diharapkan dapat memperluas pengetahuan dan wawasan penulis mengenai pengendalian internal atas persediaan,

2. Bagi pihak perusahaan, hasil penelitian ini diharapkan dapat menjadi bahan pertimbangan atau masukan yang berkaitan dengan pengendalian internal atas persediaan.

3. Bagi pihak-pihak lain, khususnya bagi almamater UNSRAT Fakultas Ekonomi \& Bisnis, hasil penelitian ini dapat dijadikan sebagai bahan referensi bagi penelitiannya.

\subsection{SistemAkuntansi}

\section{TINJAUAN PUSTAKA}

Sistem akuntansi (accounting system) adalah metode dan prosedur, untuk mengumpulkan, mengklasifikasikan, mengikhtisarkan, dan melaporkan informasi operasi dan keuangan sebuah perusahaan. (Carl S. Warren, James M. Reeve, dan Philip E. Fees, 2006:234).

\subsection{Persediaan}

\subsubsection{Pengertian Persediaan}

Ikatan Akuntansi Indonesia (2007:14.3) menjelaskan bahwa pengertian persediaan yaitu :

a. Tersedia untuk dijual dalam kegiatan usaha normal;

b. Dalam proses produksi dan atau dalam pengadaan; atau

c. Dalam bentuk bahan atau perlengkapan (supplies) untuk digunakan dalam proses produksi atau pemberian jasa. 
Persediaan (inventory) adalah pos-pos aktiva yang dimiliki oleh perusahaan untuk dijualdalam operasi bisnis normal, atau barang yang akan dijual (Kieso et al, $2008: 402$ )

\subsubsection{Jenis- JenisPersediaan}

Menurut Santoso (2010: 240) Pengelompokkan persediaan juga didasarkan pada jenis persediaannya, yaitu :

a. Bagi perusahaan dagang (merchandise enterprise) di mana persediaan merupakan barang yang langsung diperdagangkan tanpa mengalami proses lanjutan.

b. Sedangkan pada perusahaan industri di mana persediaan bahan baku memerlukan proses lebih lanjut agar siap dijual dalam bentuk barang jadi (finished goods), maka persediaan dikelompokkan sebagai berikut :

1) Bahan baku (raw material) yaitu bahan baku yang akan diproses lebih lanjut dalam proses produksi.

2) Barang dalam proses (work in process/goods in process) yaitu bahan baku yang sedang diproses di mana nilainnya merupakan akumulasi biaya overhead (factory overhead cost).

3) Barang jadi (finish goods) yaitu barang jadi yang berasal dari barang yang telah selesai diproses dan telah siap untuk dijual sesuai dengan tujuannya.

4) Bahan pembantu (factory/manufacturing supplies) yaitu bahan pembantu yang dibutuhkan dalam proses produksi namun tidak secara langsung dapat dilihat secara fisik pada produk yang dihasilkan.

\subsubsection{Sistem Pencatatan Persediaan}

Menurut(Santoso, 2010 : 241) Sistem pencatatan pengelolaan persediaan yang dimaksud dapat dilakukan dengan 2 cara yaitu :

1. $\quad$ Sistem persediaan periodik/fisik (periodical physical inventory system).

Suatu sistem pengelolaan persediaan di mana dalam penentuan persediaan dilakukan melalui perhitungan secara fisik (physical counting) yang lazim dilakukan pada setiap akhir periode akuntansi dalam rangka penyiapan laporan keuangan.

2. $\quad$ Sistem persediaan terus-menerus (perpetual inventory system).

Merupakan suatu sistem pengelolaan persediaan di mana pencatatan mutasi persediaan dilakukan secara terus-menerus dan berkesinambungan sehingga mutasi persediaan selama satu periode termonitor dan setiap saat jumlah maupun nilai persediaan dapat diketahui tanpa melakukan perhitungan fisik.

Menurut(Santoso, 2010 : 248) Ada beberapamacammetodepenilaianpersediaan yang umumdigunakanyaitu :

1. Last-in, First-out (LIFO)

2. First-in, First-Out (FIFO)

3. Average cost

4. Identifikasi Khusus (Specific identifications)

\subsection{Pengendalian Internal}

\subsubsection{Pengertian Pengendalian Internal}

Pengendalian internal merupakan satu proses yang dipengaruhi oleh dewan direksi perusahaan, manajemen, dan personel lain yang dirancang untuk memberikan jaminan yang masuk akal terkait dengan tercapainya tujuan berikut : (1) reliabilitas pelaporan keuangan, (2) efektivitas dan efisiensi operasi, dan (3) kesesuaian dengan peraturan dan regulasi yang berlaku. (Bodnar \& Hopwood, 2006 : 129).

Menurut Mulyadi (2008:163) Pengendalian Intern adalah bahwa pengendalian internal meliputi struktur organisasi, metode dan ukuran-ukuran yang dikoordinasikan untuk menjaga kekayaan organisasi, mengecek ketelitian dan keandalan data akuntansi, mendorong efisiensi dan mendorong dipatuhinya kebijakan manajemen.

\subsubsection{Unsur - UnsurPengendalian Internal}

MenurutBodnar\& Hopwood (2006 : 129) menyatakan bahwa komponen pengendalian internal meliputi : 
1. LingkunganPengendalian

2. Penilaian risiko

3. Aktivitas pengendalian

4. InformasidanKomunikasiAkuntansi

5. Pengawasan

\subsubsection{LingkunganPengendalian}

Lingkungan pengendalian merupakan dampak kumulatif atas faktor - faktor untuk membangun, mendukung, dan meingkatkan efektivitas kebijakan dan prosedur tertentu (Bodnar \& Hopwood, 2006 :133).

a. Integritas Dan Nilai -Nilai Etis

b. Komitmen pada Kompetensi

c. Partisipasi Dewan Komisaris dan Komite Audit

d. Filosofi dan Gaya Operasi Manajemen

e. Struktur Organisasi

\subsubsection{PenilaianRisiko}

Penilian risiko merupakan proses identifikasi dan analisis risiko- risiko yang berdampak terhadap pencapaian tujuan organisasi serta menentukan tindakan yang tepat untuk menghadapi risiko- risiko tersebut (Kurniawan, $2012: 112$ ).

\subsubsection{AktivitasPengendalian}

Aktifitas pengendalian merupakan kebijakan dan prosedur untuk membantu memastikan bahwa tindakan yang diperlukan untuk mengatasi risiko telah diambil guna mencapai tujuan entitas (Heri, $2011: 93)$
a. PemisahanTugas
b. Otorisasi yang tepatatastransaksi
c. Dokumendancatatan yang memadai
d. PengendalianFisikatasaktivadancatatan
e. PemeriksaanIndependen

\subsubsection{InformasidanKomunikasiAkuntansi}

Informasi yang dibutuhkan harus diidentifikasi, diterima dan dikomunikasikan dalam bentuk -bentuk dan periode yang memungkinkan para pegawai agar dapat memenuhi tanggung jawabnya.

\subsubsection{Pengawasan}

Pengawasan atau monitoring merupakan komponen pengendalian internal yang kelima, melibatkan proses yang berkelanjutan untuk menaksir kualitas pengendalian internal dari waktu ke waktu serta untuk mengambil tindakan koreksi yang diperlukan (Bodnar dan Hopwood 2006:145).

\subsection{PenelitianTerdahulu}

Nurmailiza (2009) skripsidenganjudulAnalisisPengendalian Intern ataspersediaanbarangdaganganpada PT. SabdaCipta Jaya. Salangka (2013) skripsidenganjudul : "PenerapanAkuntansiPersediaanUntukPerencanaan Dan Pengendalian LPG Pada PT. Emigas Sejahtera Minahasa.

\section{METODE PENELITIAN}

\subsection{Jenis Penelitian}

Dalam penelitian ini, penulis menggunakan jenis metode penelitian deskriptif kualitatif. Penelitian dilakukan pada kondisi yang alamiah langsung ke sumber data, pengumpulan data menggunakan instrument penelitian dan data yang terkumpul berupa profil perusahaan, visi dan misi perusahaan, struktur organisasi, job description, serta prosedur pengadaan dan pengeluaran beras pada Perum Bulog Divre Sulut. 


\subsection{Tempat dan Waktu Penelitian}

Penelitian ini dilakukan di Perusahaan Umum (Perum) Badan Urusan Logistik (BULOG) Divisi Regional (Divre) Sulawesi Utara yang beralamat di Jalan Diponegoro N0 7-8 Manado. Waktu penelitian secara keseluruhan dilakukan selama 3 bulan, sejak bulan agustus sampai oktober 2013.

\subsection{ProsedurPenelitian}

Prosedur penelitian adalah sebagai berikut.

1. MengajukanPermohonanPenelitian

Penulis memasukan surat permohonan penelitian yang sudah disetujui dari Fakultas Ekonomi untuk melakukan penelitian pada objek yang akan digunakan

2. DisposisiPimpinan

Pimpinanperusahaanmemberiperintahkepadabawahannya untuk membuat dan memberikan surat perintah yang menjelaskan tentang izin persetujuan penelitian diPerumBulogDivreSulut

3. Pengumpulan Data

Pada tahap ini, penulis mulai mengumpulkan data pendukung penelitian yang akan digunakan dalam penyusunan skripsi

4. Analisis Data Penelitian

Pada tahap ini, penulis melakukan analisis data dan memahami mengenai pengendalian internal persediaan yang diterapkan oleh perusahaan kemudian mengolah data yang tersedia dan mengevaluasinya sesuai dengan teori- terori yang ada.

5. Kesimpulan

Pada tahap ini, penulis menarik kesimpulan mengenai hasil penelitian yang telah dilakukan.

\subsection{MetodePengumpulan Data}

\subsubsection{Jenis Data}

1. Data Kualitatif

Data yang tidak dapat diukur dalam skala numerik atau dalam angka. Data Kualitatif diperoleh melalui berbagai macam teknikpengumpulan data misalnya wawancara, analisis dokumen atau observasi.

\section{Data Kuantitatif}

Data yang diukur dalam suatu skala numerik atau dalam angka. Data kuantitatif tidak digunakan dalam penelitian ini.

\subsubsection{Sumber Data}

\section{Data Primer,}

Merupakan data yang diperoleh langsung dari perusahaan atau data yang terjadi di lapangan yang diperoleh dari teknik wawancara.

\section{Data Sekunder}

Merupakan data yang diperoleh dari perusahaan dalam bentuk yang sudah jadi, seperti data mengenai sejarah singkat perusahaan, struktur organisasi, tentang pembagian tugas, dan data lengkap lainnya yang berhubungan dengan pengendalian internal persediaan perusahaan.

\subsubsection{TeknikPengumpulan Data}

1. Wawancara, yaitu penulis melakukan serangkaian tanya jawab secara langsung dengan pihak perusahaan yang berwenangyaitu bagian gudang dan akuntansi untuk mengetahui lebih jelas mengenai pengendalian internal persediaan perusahaan.

2. Observasi, yaitu mengadakan pengamatan secara langsung terhadap objek yang akan diteliti untuk mendapatkan data - data yang diperlukan sehubungan dengan kepentingan penelitian.

3. Dokumentasi yaitu informasi yang berasal dari catatan atau dokumen penting yang dimiliki perusahaan.

\subsection{MetodeAnalisis}

Dalampenelitianini, penulis menggunakan metode analisis deskriptif yaitu suatu metode pembahasan permasalahan yang sifatnya menguraikan, menggambarkan, membandingkan dan menerangkan suatu keadaan yang bertujuan untuk mendapatkan gambaran yang jelas dan terperinci mengenai suatu 
keadaan berdasarkan data atau informasi yang telah didapatkan, kemudian dikumpulkan sehingga didapatkan informasi yang diperlukan untuk menganalisis masalah yang ada.

\section{HASIL PENELITIAN DAN PEMBAHASAN}

\section{HasilPenelitian}

\section{Prosedur Pengadaan/ PermintaanPersediaan Beras}

1) Seksi pengadaan melakukan kontrak dengan mitra kerja. Dan menerima surat perintah terima barang dan barang.

2) Gudang menerima beras dan melakukan survey kualitas beras. Kemudian membuat bukti timbang penerimaan barang.Dari bukti timbang ini selanjutnya akan dibuat catatan pemasukan barang yang akan diserahkan ke seksi pengadaan untuk melakukan pengecekan atas kelengkapan dokumen.

3) Seksi pengadaan membuat bukti verifikasi pembayaran yang akan diserahkan ke seksi akuntansi.

4) Seksi akuntansi mencatat dan mengecek dokumen apakah dokumen tersebut sudah lengkap kemudian diserahkan ke seksi keuangan.

5) Seksi keuangan membuat surat perintah pembayaran yang akan diserahkan kepimpinan untuk disetujui. Kemudian akan diserahkan ke Bank.

\section{Prosedur PengeluaranPersediaan Beras}

1) Prosedur pengeluaran beras berasal dari Surat perintah alokasi yang berasal dari Pemda ke Divre.

2) Kepala Divre melakukan disposisi sesuai dengan surat perintah pengeluaran beras kepada bidang pelayanan publik

3) Bidang pelayanan publik menerima Surat Perintah Alokasi (SPA) dari kepala Divre dan memverifikasi dokumen tersebut kemudian akan diserahkan ke seksi penyaluran.

4) Seksi Penyaluran membuat DO pengeluaran beras berdasarkan Surat Perintah Alokasi. Kemudian DO tersebut diserahkan ke bidang pelayanan publik untuk disetujui. Setelah disetujui diserahkan kembali ke gudang.

5) Gudang menerima DO yang telah di setujui. Berdasarkan DO tersebut gudang mengeluarkan beras dan membuat bukti timbang penyerahan barang. Kemudian gudang akan membuat laporan pengeluaran beras (GD1k) yang akan diserahkan ke bagian akuntansi untuk dicatat sebagai pengeluaran beras.

\section{Perhitungan Fisik Persediaan Beras}

1) Perhitungan Fisik pertama kali dilakukan oleh bagian gudang dan kemudian bagian akuntansi yang melakukan pencatatan terhadap persediaan. Bagian gudang dan bagian akuntansi ini bekerja sesuai dengan bukti - bukti yang ada dan melakukan pencatatan dan membuat laporan yang akan diserahkan ke kepala divre dan kepala bidang keuangan.

2) Kepala divre menyuruh tim pengawasan untuk mengecek laporan - laporan yang diserahkan oleh kepala bidang keuangan untuk diverifikasi hasil laporannya untuk melihat kebenaran terhadap persediaan yang ada. Setelah melakukan pengecekan kembali, tim pengawasan membuat laporan dari hasil pemeriksaannya yang kemudian diserahkan kembali kepada kepala divre. Dan laporan itu dapat menilai apakah terjadi penyelewengan terhadap persediaan beras.

\section{Pembahasan}

\section{UnsurUnsurPengendalian Internal Persediaan}

\section{LingkunganPengendalian Internal Persediaan}

Manajemen Pada Perum Bulog Divre Sulut menganggap bahwa lingkungan pengendalian terhadap persediaan yang ada digudang sangat penting. Lingkungan pengendalian atas persediaan pada Perum 
Bulog Divre Sulut akan di analisa dan di evaluasi berdasarkan faktor-faktor yang menyusun lingkungan pengendalian dari perusahaan.

\section{a. Integritas Dan Nilai -Nilai Etis}

Integritas dan nilai -nilai etis yang diterapkan Perum Bulog Divre Sulut telah berjalan cukup baik. Hal ini didukung dengan adanya pernyataan kebijakan dan aturan pelaksanaan yang telah dibuat oleh manajemen sudah jelas terdapat pada perusahaan sehingga perusahaan dapat memberikan contohcontoh yang baik pada karyawan dengan mengajarkan mengenai integritas dan kode etik yang harus dipatuhi.Peraturan dan kebijakan kode etik perusahaan melatih karyawan untuk bersikap jujur dan menjunjung tinggi peraturan yang ada pada perusahaan.

b. Komitmen pada kompetensi

Perum Bulog Divre Sulut mempunyai pegawai yang cukup berkompeten. Dengan mempertimbangkan keahlian, pendidikan serta pengalaman yang dimiliki calon pekerja dalam merekrut karyawan. Misalnya dalam penempatan karyawan di bidang keuangan untuk penerimaan maupun pengeluaran kas, perusahaan memilih calon karyawan yang memiliki latar belakang pendidikan lulusan sarjana ekonomi.Perusahaan juga mempertimbangkan dalam perekrutan pegawai baru yang telah memiliki pengalaman kerja.

c. Penetapan Wewenang dan Tanggung Jawab

Penetapan wewenang dan tanggung jawab dalam pengendalian internal persediaan sudah cukup baik dilakukan oleh manajemen Perum Bulog Divre Sulut. Hal ini dapat dilihat dengan adanya pemisahan fungsi dan pendelegasian wewenang kepada setiap anggota sesuai dengan kemampuan dan keterampilan yang dimilikinya.

d. Partisipasi Dewan Komisaris dan Komite Audit

Dewan komisaris dan komite audit Perum Bulog Divre Sulut berkedudukan di kantor pusat Jakarta. Namun kantor pusat akan mengirim tim audit untuk mengadakan pemeriksaaan terhadap pelaksanaan pengendalian internal persediaan beras dengan cara meminta laporan rutin dari manajemen serta mengevalasinya. Hal ini sudah cukup efeketif bagi Perum Bulog Divre Sulut.

e. Falsafah dan Gaya Manajemen Operasi

Falsafah manajemen yang diterapkan Perum Bulog Divre Sulut dalam hal ini bertanggung jawab atas arus keluar-masukya persediaan beras telah mendukung terciptanya lingkungan pengendalian yang memadai. Hal ini dapat dilihat dengan adanya keseriusan petugas bagian gudang dalam pengelolaan akan beras yang bermutu bagi kebutuhan masyarakat.

Gaya operasi manajemen menekankan pentingnya laporan-laporan yang menunjukkan informasi yang benar/wajar tentang transaksi yang berhubungan dengan persediaan beras bagi masyarakat, baik laporan penerimaan pengeluaran beras ,laporan stock opname, dan laporan lainnya. Dalam hal ini laporan-laporan tersebut dihasilkan melalui prosedur-prosedur yang telah ditetapkan serta dilengkapai oleh bukti-bukti kompeten yang cukup, sehingga tercipta lingkungan pengendalian yang efektif.

f. Struktur Organisasi Perusahaan

Struktur organisasi di Perum Bulog Divre Sulut telah dirancang dan disusun dengan baik, yaitu secara fungsional yang terdiri dari bagian pengadaan, bagian penyaluran, bagian administarsi dan keuangan, serta bagian gudang.Penyusunan struktur organisasi berdasarkan fungsi ini sesuai untuk Perum Bulog Divre Sulut karena akan terlihat dengan jelas pembagian tugas dan wewenang dari setiap fungsional yang ada di perusahaan, sehingga pengendalian dapat dilakukan dengan lebih baik lagi di Perum Bulog Divre Sulut.

g. $\quad$ Praktek dan Kebijakan Karyawan

Kebijakan dan prosedur staff dan kepegawaian Perum Bulog Divre Sulut ini telah diterapkan cukup baik, hal ini memegang peranan yang penting bagi jalannya pengawasan karena pegawai merupakan komponen yang penting dalam pelaksanaan pengendalian internal perusahaan.Perum Bulog Divre Sulut telah menerapkan kebijakan perekrutan, pelatihan dan memberi penghargaan sesuai dengan tanggung jawab setiap pegawai yang berprestasi. Kondisi seperti ini sudah baik untuk membina kualitas pegawai yang jujur, terampil dan memiliki loyalitas terhadap perusahaan. 


\section{Penilaian Resiko}

Penilaian risiko yang dilakukan oleh manajemen agar penyajian informasi persediaan beras adalah wajar dan tepat waktu sudah cukup baik. Manajemen telah mengenali dan mempelajari resiko resiko yang ada, serta membentuk aktivitas - aktivitas pengendalian yang diperlukan untuk menghadapi hal tersebut.

Perum Bulog Divre Sulut yang tugasnya sebagai pengadaan beras melakukan penilaian terhadap persediaan beras yang masuk maupun yang keluar. Penilaian persediaanya dengan menjaga mutu beras yang ada di gudang sehingga pengawasan terhadap persediaannya dapat terjamin. Selain itu, Penilaian terhadap resiko persediaan yang dilakukan oleh Bulog adalah membuat laporan dan analisa terhadap catatan - catatan persediaan beras yang ada pada bulog dan pelaporan serta penganalisaan fisik prsediaan. Agar ketersediaan beras di Perum Bulog Divre Sulut tercukupi, perusahaan mengadakan stok opname yang memeriksa kebenaran/ kewajaran jumlah maupun kualitas beras yang ada digudang. Pemeriksaan fisik ini dapa memperkecil resiko atas penumpukan, kekurangan, atau kualitas beras yang rusak.

\section{Informasi dan Komunikasi}

Sistem informasi dan komunikasi yang dilakukan oleh Perum Bulog Divre Sulut sudah cukup baik. Hal ini dapat dilihat dari penyusunan prosedur yang jelas di dalam perusahaan, termasuk dalam prosedur pengawasan persediaan beras yang melibatkan beberapa fungsi terkait, dokumen dan catatan yang diperlukan serta laporan yang dihasilkan dan pencatatan ke dalam catatan akuntansi harus di dasarkan atas laporan sumber yang dilampiri dengan dokumen pendukung yang lengkap yang diotorisasi oleh pihak yang berwenang. Namun adanya sistem manual yang dilakukan oleh Perum Bulog Divre Sulut memberikan keterlambatan informasi dan komunikasi dibandingkan dengan menggunakan sistem yang terkomputerisasi. Menurut penulis dengan masih menggunakan sistem manual akan mengakibatkan kurangnya ketelitian dalam penilaian dan pengelolaan persediaan sehingga pengendalian internal terhadap persediaan menjadi terhambat akibat informasi dan komunikasi yang kurang baik.

\section{Aktivitas Pengendalian}

a. Pemisahan Tugas

Perum Bulog Divre Sulut telah mengadakan pemisahan tugas yang cukup pada setiap transaksi atau kegiatan yang berkaitan dengan persediaan beras, sehingga hal ini sudah mencerminkan terciptanya pengendalian internal dalam perusahaan. Dimana setiap fungsi yang ada di Bulog telah melakukan tugas utamanya masing masing. Satu diantaranya adalah pada aktifitas perhitungan fisik persediaan beras, dapat dilihat bahwa ada pembagian tugas yang jelas, yakni melaporkan jumlah persediaan beras dalam perhitungan fisik persediaan terdiri dari kepala bidang keuangan, bidang penyaluran, pimpinan , serta beberapa petugas dari bagian gudang. Adanya pembagian tugas di tiap - tiap bagian dengan fungsi kerja masing - masing memberikan peluang yang kecil di Perum Bulog Divre Sulut dalam melakukan kecurangan atau memanipulasi data ataupun penghilangan terhadap persediaan secara fisik maupun data.

\section{b. Otorisasi yang tepat atas transaksi}

Otorisasi atas transaksi dan aktivitas dilakukan dengan pembubuhan tanda tangan oleh orang yang berwenang pada dokumen untuk menyetujui terjadinya transaksi tersebut. Dengan demikian, sistem otorisasi akan menjamin dihasilkannya dokumen pembukuan yang dapat dipercaya. Misalnya dalam transaksi untuk pengeluaran beras dari gudang, bukti Delivery Order harus di otorisasi oleh bagian bidang pelayanan publik sehingga dengan adanya otorisasi tersebut maka gudang dapat mengeluarkan beras. Dengan adanya otorisasi tersebut akan mencegah adanya kecurangan dan penyelewengan yang dilakukan pegawai. Apabila terjadi kehilangan atau kesalahan data atau dokumen maka pegawai tersebut bertanggung jawab atas otorisasi tersebut. Menurut penulis Perum Bulog Divre Sulut dalam melakukan pemberian otorisasi atas transaksi dan aktivitas ini sudah cukup memadai dan harus terus mempertahankan adanya sistem otorisasi sehingga memperkecil adanya kemungkinan terjadinya kecurangan yang menimbulkan kerugaian yang besar pada perusahaan. Hal tersebut dilakukan untuk memperkuat pengendalian internal yang terdapat didalam perusahaan.

c. Dokumen dan catatan yang memadai 
Dokumen yang terdapat dalam prosedur penerimaan dan pengeluaran beras di Perum bulog Divre Sulut sudah cukup lengkap, seperti Surat Perintah Alokasi, Surat Perintah Terima Barang, Delivery Order, Bukti Timbang Penerimaan dan Penyerahan Barang, GD1k, GD1m, dan Surat Perintah Pembayaran. Dokumen-dokumen pendukung pada kegiatan penerimaan dan pengeluaran beras telah memiliki nomor urut tercetak. Hal ini mempermudah dalam pengawasan atas persediaan sehingga apabila terjadinya kesalahan atau kecurangan yang dilakukan oleh pegawai dapat segera diketahui.

d. Pengendalian Fisik atas aktiva dan catatan

Perlindungan fisik atas persediaan beras Perum Bulog Divre Sulut sudah cukup efektif, yakni dengan tersedianya gudang sebagai tempat penyimpanan. Namun agar perlindungan fisik digudang dapat terjaga dengan baik, sebaiknya Perum Bulog Divre Sulut menggunakan kamera CCTV, penggunaan kamera CCTV ini dapat membantu perusahaan untuk memperkecil adanya pencurian beras digudang yang akan dilakukan oleh pihak - pihak yang tidak bertanggungjawab. Perlindungan fisik terhadap dokumen-dokumen dan catatan-catatan juga dilakukan dengan baik, yaitu dokumen-dokumen dan catatan-catatan tersebut disimpan dan diarsip dalam blinder map sebagi tempat penyimpanan dan tetap menyimpan catatan-catatan yang rusak dalam catatan manual.

e. $\quad$ Pemeriksaan Independen

Pemeriksaan Independen yang dilakukan oleh Perum Bulog Divre Sulut sudah cukup memadai. Dimana Kebijakan perusahaan ini secara tidak langsung menciptakan suatu pengecekan yang independen di antara bagian- bagian yang melakukan permintaan atas barang maupun yang mengeluarkan barang. Pemeriksaan dilakukan secara periodik yaitu 3 bulan sekali oleh Kepala Bulog, kepala bagian keuangan, dan tim pengawasan. Pengecekan independen ini bertujuan agar meminimalkan terjadinya penyelewengan dalam perusahaan.

\section{Pengawasan}

Pengawasan/Pemantauan yang dilakukan oleh Perum Bulog Divre SULUT dimulai dari bagian gudang sebagai sumber keluar dan masuknya persediaan beras dan juga bagian pencatatan persediaan di bagian akuntansi. kemudian bagian ini dipantau oleh Kapala Gudang dan kabid. Keuangan dan di teruskan ke Kabulog. Perum Bulog Divre SULUT melakukan pemantauan persediaan beras dengan melakukan stok opname setiap harinya dan juga sering adanya inspeksi mendadak yang dilakukan. Aktivitas pemantauan yang dilakukan sudah cukup baik dalam mendukung terciptanya pengendalian internal yang memadai dalam perusahaan.

\section{Kesimpulan}

\section{PENUTUP}

1. Lingkungan pengendalian persediaan pada Perum Bulog Divre Sulut terdapat struktur organisasi yang berbentuk fungsional, dimana pembagian tugas tugas sudah dilakukan kesetiap bagian sehingga tidak ada penggandaan tugas. Serta mempunyai pegawai yang berkompeten dalam bidangnnya untuk menyelesaikan tugas yang diberikan. Hal ini sudah mencerminkan prinsip pemisahaan fungsi yang baik dalam pengendalian internal perusahaan.

2. Penilaian resiko yang dilakukan oleh Perum Bulog Divre Sulut atas persediaan beras sudah cukup memadai. Hal ini bisa dilihat dengan adanya penjagaan kualitas beras di gudang sehingga bisa disalurkan kepada masyarakat. Perusahaan juga telah membuat kebijakan stock opname secara rutin setiap hari untuk mengatasi resiko persediaan beras yang rusak atau adanya penyelewengan.

3. Pelaksanaan informasi dan komunikasi atas persediaan beras secara umum masih memadai untuk mendukung pengendalian internal. Fungsi-fungsi yang terkait, prosedurprosedur, dokumen, dan catatan yang diperlukan dibentuk dan dikoordinasikan sedemikian rupa agar informasi persediaan beras yang wajar dapat dihasilkan dan dikomunikasikan setiap hari. Namun kelemahan perusahaan dalam kemampuan informasi dan komunikasi masih menggunakan sistem manual sehingga untuk mempertahankan akuntabilitas keakuratan data dan kecepatan informasi kurang dimaksimalkan walaupun telah memenuhi unsur - unsur pengendalian internal.

4. Aktivitas pengendalian yang dilakukan terhadap pelaksanaan transaksi penerimaan dan pengeluaran beras juga masih memadai. Setiap transaksi yang terjadi juga telah diotorisasi oleh pegawai yang berwenang dan dokumen-dokumen yang digunakan dalam setiap transaksi tersebut telah memiliki nomor urut tercetak. Pengawasan fisik atas persediaan dan catatan, serta pemeriksaan 
independen atas pelaksanaan kinerja perusahaan juga telah memadai karena adanya kejelasan pelaksanaan tugas dan tanggung jawab.

5. Perlindungan fisik digudang Perum Bulog Divre Sulut belum menggunakan kamera CCTV. Hal ini dapat melemahkan pengendalian internal persediaan.

6. Pemantauan terhadap persediaan pada perum Bulog Divre Sulut telah sesuai dengan pengendalian internal persediaan dimana kegiatan pemantauan persediaan dilakukan oleh kepala bulog serta dibantu oleh bagian keuangan melalui kegitan stock opnme setiap hari, 3 bulan, serta inspeksi mendadak . Dan juga telah dipantau oleh pihak ekstern yaitu BPKP.

\section{Saran}

1. Lingkungan pengendalian persediaan di Perum Bulog Divre Sulut sudah cukup memadai, hal ini dapat dilihat dari struktur organisasi yang ada di Perum Bulog Divre Sulut sudah tersusun dengan baik, dimana terdapat pemisahan tugas di masing - masing bagian dan pemisahan fungsi ini perlu di tingkatkan lagi agar pegawai dapat melaksanakan pekerjaan secara efektif dan efesien sesuai dengan kompetensi yang dimiliki, sehingga aktivitas yang terjadi didalam perusahaan menjadi lebih lancar karena setiap pegawai mengerti tugas yang harus dilaksanakan dan memang memilki keahlian yang dibutuhkan. Lebih hemat waktu dalam memberikan pelatihan dan pembelajaran, sehingga kinerja perusahaan dapat meningkat.

2. Kebijakan Perusahaan dalam menentukan resiko persediaan beras telah memadai dan harus semakin ditingkatkan lagi dengan menjaga mutu beras agar kebutuhan pangan masyarakat terpenuhi.

3. Pelaksanaan informasi dan komunikasi atas persediaan beras telah memadai dan semakin ditingkatkan dengan lebih mengefektifkan pengkoordinasian fungsi - fungsi yang terkait, prosedur prosedur, dokumen - dokumen, dan catatan yang diperlukan dalam semua transaksi persediaan. Disamping itu, perusahaan juga perlu memperbaiki sistem manualnya agar kecepatan dan ketepatan informasi dapat digunakan dengan cepat dan mengefisiensi pekerjaan bagi perusahaan dan perlu berganti kepada sistem yang telah terkomputerisasi.

4. Aktivitas pengendalian terhadap persediaan yang meliputi pemisahan tugas yang jelas pada setiap fungsi terkait dan otorisasi yang pantas atas setiap transaksi dan aktivitas agar tetap dipertahankan karena sangat berpengaruh terhadap pengecekan secara independen atas pelaksanaan kinerja perusahaan, sehingga mendukung terciptanya pengendalian internal yang baik.

5. Dalam perlindungan fisik digudang sebaiknya perusahaan memasang Kamera CCTV, agar persediaan beras digudang dapat terawasi dengan baik sehingga dapat meminimalkan tindakan pencurian terhadap persediaan yang ada digudang.

6. Aktivitas pemantauan terhadap pengendalian persediaan beras yang dilakukan oleh kepala bulog dan bagian keuangan melalui stock opname secara periodic adalah sudah cukup memadai dan ditingkatkan lagi agar terciptanya pengendalian internal persediaan berjalan dengan baik.

\section{DAFTAR PUSTAKA}

Bodnar, George H., dan William S. Hopwood, 2006. Sistem Informasi Akuntansi, Edisi Kesembilan Penerbit ANDI, Yogyakarta.

Heri. 2011. Auditig 1 : Dasar-Dasar Pemeriksaan Akuntansi, edisi pertama cetakan pertama. Penerbit Kencana, Jakarta.

2011. Akuntansi Perusahaan Jasa dan Dagang. Cetakan kesatu. ALFABETA. Bandung

Ismunandar.2005. Pengawasan Intern PersediaanPada Perusahaan UmumBulogDivisi Regional Sumatera Utara.

Kieso, Donald E., Jerry J. Weygandt and Terry D. Warfield, 2008. Akuntansi Intermediate, Diterjemahkan oleh Emil Salim, Edisi 12. Jilid 1. Penerbit Erlangga, Jakarta

Kurniawan, Ardeno, 2012 audit internal : nilai tambah bagi organisasi, Edisi pertama. BPFE,Yogyakarta

Mulyadi, 2008. Sistem Akuntansi. Edisi ketiga Cetakan ke empat. Salemba Empat,Jakarta

Niswonger, Rollin C, Carl S. Warren, James M. Reeve, Philip E. Fees, 2006.Accounting Principle, Edisi 21. Terjemahan Llyginus Raswinarto, Jakarta. 
Nurmailiza, Tengku, 2009. Analisis Pengendalian Intern Atas Persediaan Barang Dagang Pada PT. Sabda Cipta Jaya. Universitas Sumatera Utara Fakultas Ekonomi Medan.

Salangka, Ester, 2013.Penerapan Akuntansi Persediaan Untuk Perencanaan Dan Pengendalian LPG Pada PT. Emigas Sejahtera Minahasa. Jurnal EMBA. Vol.1 No.3. Hal. 1120-1128.

Santoso, iman., 2010. Akuntansi Keuangan Menengah, Cetakan Kedua Penerbit PT Refika Aditama, Bandung.

Sugiyono, 2010. Metode Penelitian Bisnis, Pendekatan Kuantitatif, Kualitatif dan R\&D. Penerbit Alfabeta. Bandung.

Ikatan Akuntan Indonesia, 2007. Standar Akuntansi Keuangan, Salemba Empat. Jakarta www. Bulog.com. 